\title{
12
}

\section{Imperial Women: Collective Biography, Gender and Yale-trained Historians}

\author{
John G. Reid
}

On 23 May 1931, a reception at Yale University marked the retirement of Charles McLean Andrews from the Department of History. At 68 years of age, Andrews had completed some 42 years as an active historian - at Bryn Mawr College from 1889 to 1907, at Johns Hopkins University from 1907 to 1910, and at Yale thereafter - since receiving his doctorate from Johns Hopkins and publishing his dissertation on The River Towns of Connecticut: A Study of Wethersfield, Hartford, and Windsor. ${ }^{1}$ Although, as the son of a prominent clergyman of the short-lived Catholic Apostolic Church who lived and made his evangelical base in Wethersfield, Andrews had written a dissertation that was in a sense a local study of his own home territory, his interests as a historian were nevertheless wide-ranging. Much of his early post-dissertation work was in English medieval history, but increasingly he moved into American history of the colonial era. Indeed, as Richard R. Johnson argued some years ago, he can properly be

1 Charles McLean Andrews, The River Towns of Connecticut: A Study of Wethersfield, Hartford, and Windsor, Johns Hopkins University Studies in History and Political Science, Seventh Series, VII-VIII-IX (Baltimore: Johns Hopkins University, 1889). I am very grateful to my research assistant Samantha Bourgoin for the thorough biographical reconnaissance that was foundational to this essay, and also to Michael Frost and other staff members in Manuscripts and Archives, Yale University Library. 
regarded as having defined and originated US colonial history as a historical field. ${ }^{2}$ By the time that Andrews was publishing his multivolume work, The Colonial Period of American History - the first volume of which won him the 1935 Pulitzer Prize for History - his emphasis on the institutions that bound the colonies to the metropolis had been communicated to many of his graduate students and would lead to his posthumous historiographical designation as the founder and leader of the 'imperial school'. ${ }^{3}$ His own view, however, was that his contribution was to colonial rather than imperial history, as he explained in 1926 to one of his recent doctoral graduates:

Approaching the colonies from the English side, and so seeing them in quite a new light, showed me that they had never been properly studied before and that their history could not be understood when interpreted - as was ordinarily the case - in the American field only. I saw that the 'colonial' aspect had been almost entirely left out and it is that aspect that I have tried to present. ${ }^{4}$

It was thus appropriate that the centrepiece of Andrews's retirement reception was the presentation of a Festschrift entitled Essays in Colonial History Presented to Charles McLean Andrews by his Students. ${ }^{5}$ The book contained 12 essays, nine contributed by Yale $\mathrm{PhD}$ graduates. One author, Mary Patterson Clarke of Beaver College in Pennsylvania, was still working on the Yale dissertation she would complete in the following year, while two others were $\mathrm{PhD}$ graduates from Johns Hopkins. Nellie Neilson, the Mount Holyoke scholar who was later to become the first woman president of the American Historical Association and who in 1931 could reasonably be seen as Andrews's most distinguished former student, had studied with him at Bryn Mawr in his earlier field of interest and so, 'hopelessly mediaeval by nature', she could 'make no scholarly contribution in his honor to this volume of colonial studies', but instead wrote the Introduction. ${ }^{6}$ Of the 12 authors of the substantive essays, four

2 Richard R. Johnson, 'Charles McLean Andrews and the Invention of American Colonial History', William and Mary Quarterly, 3rd series, 43:4 (October 1986), 519-41. Andrews had also been the subject of an intellectual biography published some 13 years after his death in 1943: A.S. Eisenstadt, Charles McLean Andrews: A Study in American Historical Writing (New York: Columbia University Press, 1956).

3 Johnson, 'Charles McLean Andrews', 528-9.

4 Charles McLean Andrews (hereafter CMA) to Hastings Eells (copy), 5 March 1926, Charles McLean Andrews Papers (MS 38), Manuscripts and Archives, Yale University Library (hereafter CMAP), Box 24, Folder 289.

5 Essays in Colonial History Presented to Charles McLean Andrews by his Students (New Haven: Yale University Press, 1931; reprinted Freeport, NY: Books for Libraries Press, Inc., 1966). The presentation copy is in CMAP, Box 98, Folder 1035.

6 Nellie Neilson, 'Introduction', in Essays in Colonial History, 1. 
were women. In addition to Clarke, Viola Florence Barnes of Mount Holyoke College contributed the lead essay, while others were authored by Isabel MacBeath Calder of Wells College and Dora Mae Clark of Wilson College. The proportion of women authors, along with their exclusive concentration in women's colleges, is already suggestive in gender terms. However, for those historians interested in the gender dimensions of the discipline of history, and in the history of academic and professional women in the twentieth-century United States, it is another part of the book that has attracted the greatest attention.

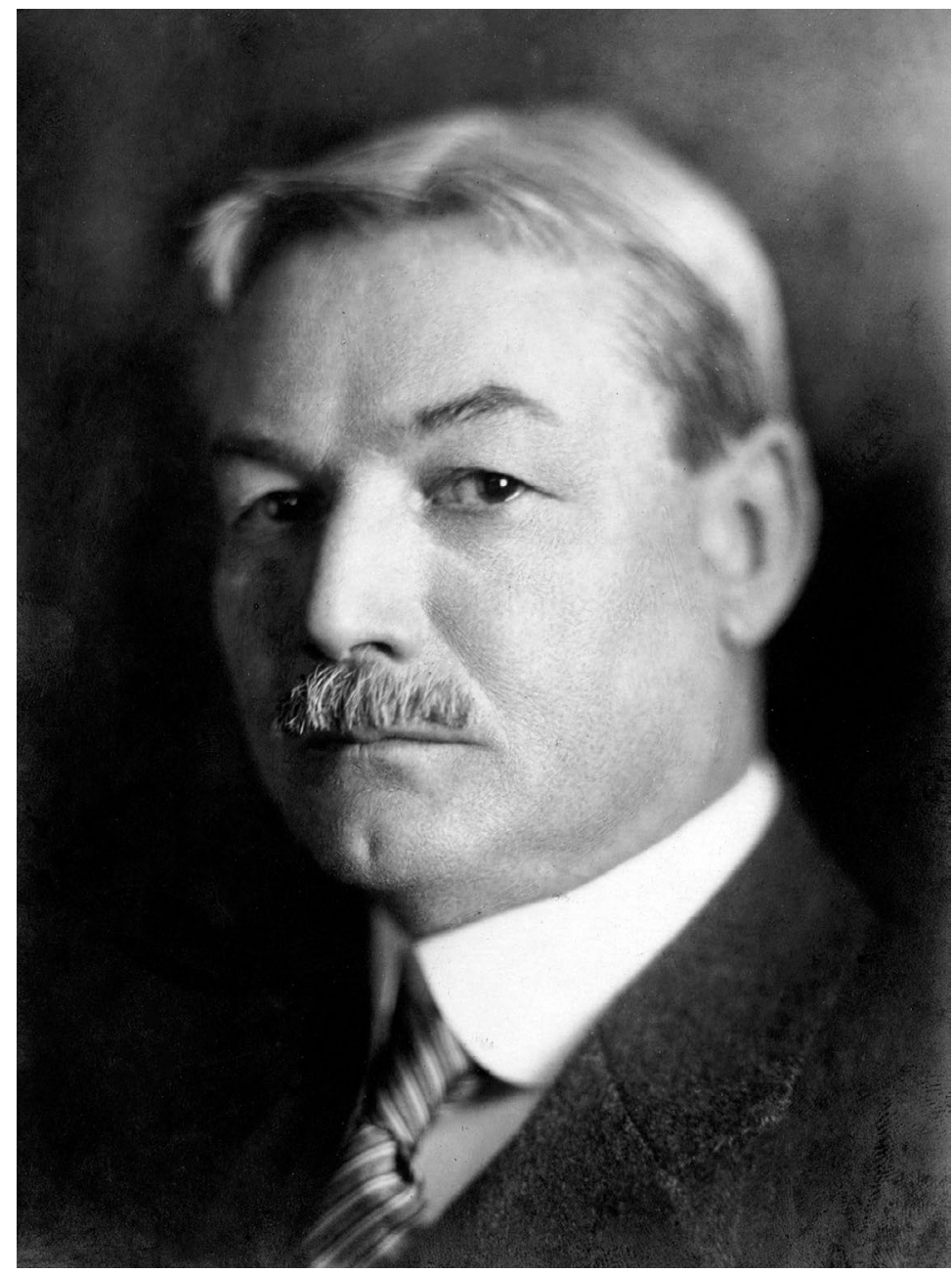

Charles McLean Andrews

Source: Courtesy of Special Collections, Sheridan Libraries, Johns Hopkins University. 


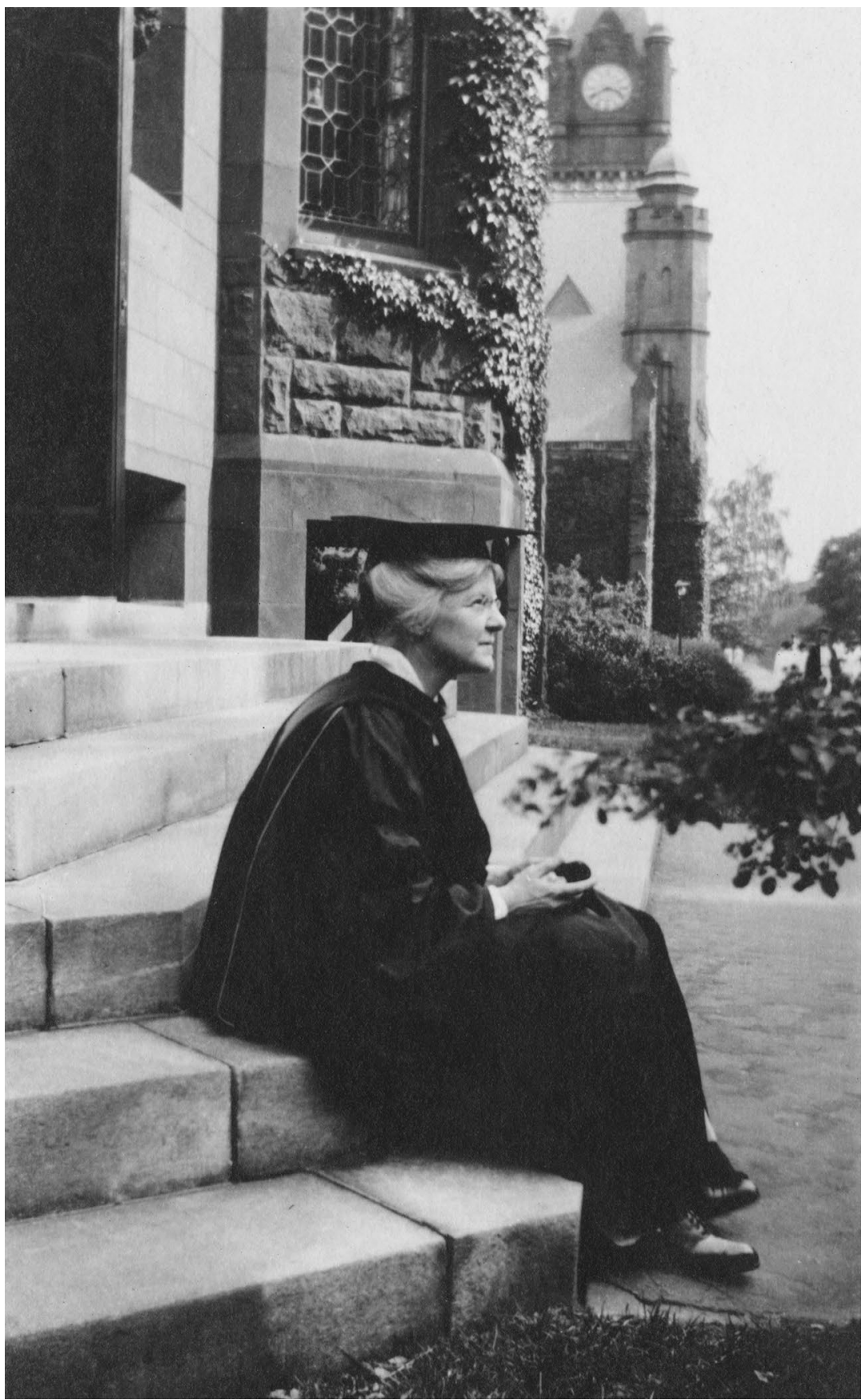

\section{Nellie Neilson}

Source: Courtesy of Mount Holyoke College Archives and Special Collections. 
The four-page Dedication of Essays in Colonial History not only affirmed to Andrews that 'for your skill as a teacher and your kindliness and sympathy as a man, your students hold you in the warmest affection', but also - in the reprinted edition of 1966 although not, oddly, in the original edition of 1931 - carried a signature list of 114 names. They comprised 50 women and 64 men. $^{7}$ The first to comment on this gender distribution, with some 44 per cent of the former students being women, was Ian K. Steele in a 1984 paper that remained unpublished; two years later, Johnson elaborated by noting that 'the fact that women composed over 40 percent of those who listed themselves as Andrews's students ... may have hampered the spread of his message and methods because of the scant opportunities then open to women for teaching at major doctorategranting schools' ${ }^{8}$ In my own biographical study of Viola Barnes, drawing on Steele and Johnson, I also cited the proportion of women who studied with Andrews as a reason for exploring Barnes's career in the context of her association with the 'imperial school'. 'Yet, as Johnson correctly pointed out in a footnote, the list of signatories includes a number who 'did not study with Andrews in the field of colonial history. ${ }^{10}$ The list, in reality, is a complex source in many respects. Not all of the signatories had been doctoral students, and some from Bryn Mawr - where Andrews had taught undergraduates, by contrast with his years at Johns Hopkins and Yale when he dealt exclusively with graduate students - had not been graduate students at all. Thus, the women listed were more varied in scholarly terms than the men, of whom 55 (or 86 per cent) had or would attain doctoral degrees compared with 21 of the women ( 42 per cent). Of the Yale graduate students, women or men, it is difficult in some cases to establish which were actually supervised by Andrews and which may have taken his seminar but were primarily supervised by others, prominently including at Yale his own former students Charles Seymour and Leonard Woods Labaree. The process by which signatories were added to the list also bears examination. It was, of course, a self-selected group, and esteem for Andrews was a precondition. If there were students who, for whatever reason, disapproved of his teaching or scholarship, or did not share in the

\footnotetext{
7 Essays in Colonial History, v-viii. The reasons for the omission of the list in 1931 are unknown, but its authenticity is corroborated by the tracing of connections to Andrews on the part of the signatories, as well as in some cases by agreements to make donations to the cost of the volume in CMAP, Box 30, Folders 347-8.

8 Johnson, 'Charles McLean Andrews', 532.

9 John G. Reid, Viola Florence Barnes, 1885-1979: A Historian's Biography (Toronto: University of Toronto Press, 2005), xiii, doi.org/10.3138/9781442628076.

10 Johnson, 'Charles McLean Andrews', 542-3, note 41.
} 
affection expressed in the Dedication, then they would by definition be excluded. The only essential qualifications for inclusion, in addition to being well disposed towards Andrews, seem to have been having at some point studied with Andrews and being willing to contribute at least $\$ 10$ to the production costs of the Festschrift. Stanley M. Pargellis, a Yale PhD graduate of 1929 and one of the five-person editorial steering group which also included Barnes, Helen Taft Manning, Frederick J. Manning and Labaree - was the chief collector, and the criteria he used for deciding who should be approached have not survived. ${ }^{11}$

Nevertheless, this essay will argue that collective biographical analysis based on the list of 114 names in Essays in Colonial History - focusing especially on the 50 women and, within that number, on those who in 1931 either had or would attain the $\mathrm{PhD}$ degree or in some other way were demonstrably associated with Andrews in a research capacity - can contribute significantly towards our understanding of the career trajectories of women historians in the United States during the twentieth century. As well as illustrating the obstacles that they - along with women in other professional fields - had to face and overcome, the analysis can also indicate the nature of the institutions and networks that lent support to their efforts. Yale was not alone in offering doctoral degrees to women. As well as Bryn Mawr and Radcliffe, Columbia, Cornell and the University of Pennsylvania offered doctoral programs in history by the early twentieth century, as did state universities further west. ${ }^{12}$ Nevertheless, the department at Yale, and Andrews's 'imperial school' in particular, offers an opportunity to explore one well-defined group of women scholars and to compare their experiences directly in some respects with those of their male colleagues.

A report drafted for the Yale graduate school during the 1919-20 year, which had clearly been influenced by initiatives led by Viola Barnes on behalf of the women graduate students, claimed that 'Yale has done pioneer work in making the facilities for higher education available to women', but went on to enumerate a series of difficulties that women

11 See the correspondence in CMAP, Box 30, Folders 347-8; the editorial group is named in Essays in Colonial History, vii.

12 Julie Des Jardins, Women and the Historical Enterprise in America: Gender, Race, and the Politics of Memory, 1880-1945 (Chapel Hill: University of North Carolina Press, 2003), 34-5. For a valuable contemporary analysis of the availability of PhDs to women in the United States from 1877 to 1927, although with limited differentiation of history as a field, see Emilie J. Hutchinson, Women and the Ph.D. (Greensboro: North Carolina College for Women, 1929), esp. $20-7$. 
graduate students encountered that ranged from dining and residential restrictions to the inaction of the Board of Appointments in finding professional placements for women. ${ }^{13}$ With the publication in 1920 of a booklet for which the report had been a precursor, pride in achievement took a higher priority. Andrews himself contributed the section on graduate programs in history, including a biographical directory of the 12 women who to that point had gained PhDs. His analysis, that 'two of the twelve are investigators [researchers], four more are teachers, and the remaining six have withdrawn from all connection with historical work', led to definite conclusions that he believed confirmed what he had learned also at Bryn Mawr:

With this evidence before us, it is not unreasonable to conclude that the majority of women, whose interest lies in the historical field, should be urged to attempt no more than one or two years of graduate study, for the purpose of familiarizing themselves with graduate methods and the handling of historical materials. The M.A. degree, for which two years are required, is a sufficient qualification for those who have no other aim than to teach ... On the other hand, those with special aptitude and enthusiasm, who are possessed of a fixed determination to make investigation a part of their life-work and have proved themselves competent to do so, may well be encouraged and aided to go on to the Doctor's degree. ${ }^{14}$

In the context of the significant representation of women among Andrews's research students, as shown in the list of signatories to the Festschrift, and also of the limitations thus enunciated by Andrews on his own receptiveness to women students, this essay will therefore explore through an analysis of the experience of the signatories the extent to which Yale and the 'imperial school' offered genuine scope for aspiring women historians to advance in their chosen field.

Of the 50 women signatories, 11 were Bryn Mawr students who did not take doctorates at that institution; most had been graduate students or graduate fellows, but two were undergraduates. Among the 11 was Caroline Miles Hill, who was a graduate fellow in history at Bryn Mawr in 1891-92 but took her doctorate in 1892 from the University of

13 Draft Report, [1919-20], Graduate School Records, Records of the Dean (RU 948), Manuscripts and Archives, Yale University Library, 2004-A-173, Box 1, Folder on Graduate Women, 1902-1944; the report was almost certainly prepared by Margaret Trumbull Corwin, executive secretary of the Graduate School. On Viola Barnes's advocacy, see Reid, Viola Florence Barnes, 34-5.

14 Charles McLean Andrews, 'History', in [Margaret Trumbull Corwin, ed.], Alumnae Graduate School, Yale University, 1894-1920 (New Haven: Yale University, 1920), 40-1. 
Michigan. ${ }^{15}$ Six of the signatories, however, were $\mathrm{PhD}$ graduates from Bryn Mawr: Eleanor L. Lord (1898), Nellie Neilson (1899), Ellen Deborah Ellis (1905), Marion Parris Smith (1908), Louise Dudley (1910) and Margaret Shove Morriss (1911). Of those whose connection with Andrews was through Yale, 11 were either $\mathrm{PhD}$ graduates by 1931 or would later take that degree at Yale: Viola Florence Barnes (1919), Dora Mae Clark (1924), Helen Taft Manning (1924), Isabel MacBeath Calder (1929), Gertrude Ann Jacobsen (1929), Ruth May Bourne (1931), Mildred L. Campbell (1932), Mary Patterson Clarke (1932), Mary Reno Frear (1933), Helen Stuart Garrison (1934) and Maybelle R. Kennedy (1945). Nine were MA graduates from Yale, of whom two are known later to have taken $\mathrm{PhD}$ degrees elsewhere: Bessie E. Hoon (University of London, 1934) and Sarah R. Tirrell (Columbia, 1946). A further 10 were registered at some point with the graduate school at Yale, but took no degree; one, Eleanor S. Upton, took a PhD in 1930 from the University of Chicago. There was also one other small but significant subgroup among the 50: three Scottish holders of fellowships at Yale from the Commonwealth Fund, ${ }^{16}$ comprising two who already held $\mathrm{PhD}$ degrees from the University of $\mathrm{St}$ Andrews - Edith E. MacQueen (1926) and Edith E.B. Thomson (1928) - and one - Agnes M. Whitson - who would not take a PhD but became a published author on the basis of her MA thesis from the University of Manchester. ${ }^{17}$

Thus, 21 of the 50 women were graduate students from the United States who, whether before or after they signed the list for Andrews's Festschrift, took doctoral degrees. A number of the others, in particular the three holders of Commonwealth Fund fellowships and two of the Yale MA graduates - Florence Cook Fast and Dorothy S. Towle - who continued their interest in research even after marriage had made further academic

15 Others who can be identified as graduate students were Mabel Davis, a Canadian who studied at Bryn Mawr during the 1905-06 year after taking a University of Toronto MA, and Katharine Dame, who spent a year at Bryn Mawr after taking her $\mathrm{AB}$ at Boston University. In order to avoid burdening of the footnotes to this essay with specific evidence on individual students, the sources used for each person have been gathered, along with essential biographical data, in a document entitled 'Summary of Sources for Biographical Data', posted at: library2.smu.ca/handle/01/25926.

16 Not to be confused with the Commonwealth Scholarships scheme launched in 1959, the Commonwealth Fund was a private, New York-based foundation that existed in part to provide fellowships (analogous in reverse to Rhodes Scholarships) to enable young scholars from the British Commonwealth to study in the United States.

17 For simplicity, the names of the women signatories to Andrews's Festschrift are given throughout this essay - even though a few were married names, and other signatories used married names later in life - in the form that is found on the list. 
career progress difficult, are also relevant to this essay in a qualitative sense through their correspondence with Andrews. The 21, however, provide a core group for a more basic biographical analysis, even though it must be remembered that because the list itself is far from being a scientific sample, and moreover the numbers are small, any quantification is valuable more for its ability to inform qualitative conclusions than for inherent statistical validity. Initial distinctions can be drawn in age of $\mathrm{PhD}$ graduation, both chronologically and in gender terms. Chronologically, the seven $\mathrm{PhD}$ graduates associated with Andrews through Bryn Mawr were younger when they gained the degree: 27.6 years on average, with a median of 27 , compared to 36.6 with a median of 34 for the 14 women associated with Andrews through Yale. In part, the difference undoubtedly reflects more elaborate requirements for the degree in the later years the $\mathrm{PhD}$ graduations of the Bryn Mawr group spanned the years from 1892 to 1911, the Yale group from 1919 to 1946 - and a comparable age difference is also found among the men, although not so marked: an average of 28.5 with a median of 26.5 (26 and 27) for the six linked with Andrews through Johns Hopkins, compared with 32.6 and a median of 32 for the 49 linked through Yale. Where the gender distinction is clear, according to the numbers given above, is between the Yale-linked women and men, and if only the actual Yale $\mathrm{PhD}$ graduates are considered, the difference is even more marked: an average age of 35.2 and a median of 34 for the 11 women, with an average of 31.5 and a median of 31 for the 41 men. ${ }^{18}$

For women, especially during the interwar years - the era during which all but one of the Yale women graduates and all but two of the overall Yalelinked group of women took their degrees - gaining a PhD was an extended, expensive and labour-intensive process. The Bryn Mawr graduates, small in number as they were, had family origins in the professional and business occupations of their fathers (mothers' occupations rarely appearing in surviving documentation): a minister, a lawyer, a YMCA official, merchants in tobacco and coal, and a mining engineer who was one of the founders of Standard Steel in Philadelphia. They also came mainly from the north-eastern United States, the exception being Louise Dudley, a minister's daughter from Kentucky. The Yale-linked graduates were much more diverse, in ways that also help to explain why they took

18 Because exact birthdates are not known in all cases, nor are exact graduation dates, age is taken in all cases to be the number of years reached at whatever birthday fell in the year of graduation. 
their degrees at a somewhat more advanced age than had their Bryn Mawr predecessors, in that for many of the Yale women a demanding prerequisite was the ability to support themselves. They ranged in social origins from Isabel MacBeath Calder, the daughter of Scottish immigrants whose father worked as a carpenter, to Helen Taft Manning, the occupations of whose father included lawyer, judge and 27th President of the United States. In between were two whose fathers were ministers (Hoon and Jacobsen), two university professors (Frear and Upton), and one each of physician (Clark), engineer (Garrison), small-town newspaper editor (Barnes), farmer (Campbell), liveryman (Clarke), greenhouse manager (Kennedy), shoe factory foreman (Tirrell) and pottery presser (Bourne). While it would be foolish to attempt to construct a firm ranking of these bare, mainly census-derived occupational descriptions in terms of wealth or lack of it, it is clear that - although not, of course, representing the full spectrum of US society at the time - this was no simple cohort of the daughters of affluence. These 14 women also had varied geographical origins. Unsurprisingly, the largest single group consisted of six New Englanders (three from Connecticut, and one each from Massachusetts, Rhode Island and Vermont), while another came from Pennsylvania. The remaining seven were spread from West Virginia and Ohio south to Tennessee, then west to Illinois and Kansas, and north to Nebraska and North Dakota. They had first degrees to match, although with some variations representing family moves during childhood: Bryn Mawr, Mount Holyoke and Smith College were all represented, but in general the 'Seven Sisters' were handsomely outnumbered by state universities - Nebraska, Kansas, Minnesota and others - and other institutions Northwestern, Maryville College in Tennessee - outside of the north-east.

However, when it came to careers followed after $\mathrm{PhD}$ graduation, the Seven Sisters and other women's colleges loomed much larger. Of the seven women connected to Andrews through Bryn Mawr, two (Ellis and Neilson) spent their subsequent careers at Mount Holyoke, one (Smith) at Bryn Mawr, one (Dudley) at Stephens College, Missouri, and another (Morriss) became a long-serving dean at Pembroke College, the associated women's college at Brown University. Of the remaining two, one (Lord) had spells at Smith, the Baltimore Women's College, and Goucher College, while the other (Hill) followed entirely different, non-academic career avenues. The careers of the Yale-linked women were more complex, in that five of the 14 married, including four whose husbands were academics, three of whom were other Yale graduate students. Of those who married, 
one (Garrison) appears to have had no further formal academic career, while Bessie (later preferring to be known as Elizabeth) Hoon continued to write and undertook later in life an extended visiting professorship at the coeducational Rider College in New Jersey. Another (Frear) had an early appointment at Pennsylvania State College, took a break presumably for child rearing, but after the death of her husband when she was still in her late 40s had brief sojourns at Vassar and Wellesley before spending some 15 years as dean of the faculty at the all-women Hood College in Maryland. A fourth (Kennedy) took her doctorate in 1945, long after she had first attended Yale, and by the time her book was published in 1948 she had an association with the Department of History at Smith College. Helen Taft Manning, meanwhile, had a long and uninterrupted career as an administrator and professor at Bryn Mawr, while her husband taught at nearby Swarthmore College. Of the remaining nine, six had long careers as historians at women's colleges: Barnes at Mount Holyoke, Calder at Wells, Campbell at Vassar, Clark at Wilson College in Pennsylvania, Clarke at Beaver College also in Pennsylvania and Jacobsen - who died relatively early in life, however, in 1942 - at Hunter College. Ruth Bourne had a series of positions at coeducational institutions before completing her career at California Western University, and Sarah Tirrell held administrative positions in admissions offices at Mount Holyoke and the New Jersey College for Women before taking her Columbia PhD in 1946 and taking up a professorship at the Municipal University of Omaha, later part of the University of Nebraska. Finally, Eleanor S. Upton had an earlier career as a social worker, became a librarian first at Brown University and then at Yale in 1921, took her University of Chicago PhD in 1930, and then returned to the library at Yale for the balance of her working life.

Thus, in the most general terms, the women $\mathrm{PhDs}$ associated with Andrews - and especially those whose connection was through Yale present a pattern of relatively diverse social and geographical origins, which were then distilled through graduate study into careers at institutions that were largely though not exclusively specific to women, among which prestigious colleges predominated, although again not exclusively. Yet within this overall configuration lay complex decisions and dilemmas that the women characteristically encountered. The issues centred in two areas - economic and career challenges, and those surrounding marriage 
and family - while the ability to address them effectively depended not only on the resourcefulness of the individual, along with possible support from Andrews and Yale, but also on the formation of networks to coordinate responses to common problems.

The economic and career issues, although obviously depending on the social background of each individual, began for many of the women even before reaching Yale. Among the reasons for the age - mid-30s - at which women typically took $\mathrm{PhD}$ degrees was the necessity of working and saving funds before and frequently during doctoral study and research. Of the Yale-linked women, it was common to have taught high school for a number of years prior to enrolment at Yale: Bourne, Campbell, Frear, Garrison, Hoon and Tirrell are examples. Others already had appointments at colleges, but not necessarily of the elite variety. One who felt the resulting dilemma acutely was Mary Patterson Clarke, the liveryman's daughter from Lawrence, Kansas, who was 53 years old when she took her doctorate in 1932 and had been a student of Andrews at both Bryn Mawr and Yale. ${ }^{19}$ Clarke spent most of her career - both before and after PhD graduation - at Beaver College. Although in the early 1920s she entertained thoughts of finding a position at the University of Kansas, her alma mater, or at one of the institutions in Philadelphia, she faced a constraint with which she found that the appointments bureaus at either Bryn Mawr or Yale were of no help. Characterising Beaver College as a two-year vocational school where no work at college level was possible, she found her research on the role of colonial Assemblies slow going. She wrote to Andrews in March 1925 that:

I am supporting myself and working at the same time on my assemblies, and ... I have not an oversupply of strength to bear the double burden ... After spending so much time and money and effort as I have done on this subject I cannot afford either to give it up or to rush it too much, and it is hard to think of staying in this kind of institution till it is completed and in print if that should ever occur. ${ }^{20}$

19 Mary Patterson Clarke to Evangeline W. Andrews (hereafter EWA), 14 September 1943, CMAP, Box 89, Volume I.

20 Mary Patterson Clarke to CMA, 4 March 1925, CMAP, Box 23, Folder 280; see also Clarke to CMA, 17 April 1923, CMAP, Box 22, Folder 267. 
By 1927, again casting in vain for alternatives, Clarke was even more direct:

I am caught in a 'vicious circle.' I can not get the position I want - I mean the kind of position, I have no one in mind - without my degree; I can not get the degree without finishing the book; and I can not finish the book to my satisfaction in this atmosphere. ${ }^{21}$

For Clarke, matters did eventually improve. Although still encountering heavy teaching loads at Beaver College, she conceded by the summer of 1930 that the college had 'improved until I begin to have some hope that I might sometime be less out of sympathy with the way it is managed than I always have been' and, moreover with some pushback on her part on contested points, she gained Andrews's approval of her dissertation in early 1932. ${ }^{22}$ Nevertheless, she had set out clearly and accurately the economic pressures that had slowed and threatened to stall her progress.

Ruth Bourne, meanwhile, daughter of an Indiana pottery presser, wrote to Andrews in 1928 from California, where she was teaching high school, that she hoped to apply to Yale but still had debts from working her way through college. A fellowship from the American Association of University Women proved to be a crucial support, and Bourne received her doctorate in 1931. ${ }^{23}$ Even so, and after finding employment at Bowling Green State College in Ohio, she still had debts and the pressures of the Great Depression were adding further complications: 'it is not certain yet whether my parents are going to need my assistance soon. They have double liability stock in a defunct loan company!'24 Bessie Hoon, perhaps from a more financially secure though certainly not wealthy background as a minister's daughter from Illinois, by age 24 had already headed a high school history department and had gained two degrees including a Yale MA. In early 1930, she hoped to find a college or university teaching position prior to turning fully to research. 'I realize,' she commented to Andrews, 'that as a woman competing with men such a position may not be easy to locate; the lack of a $\mathrm{PhD}$ perhaps will handicap me, but on the other hand I have absolute confidence in my own ability to fill such a position if it can be located. ${ }^{25}$ Hoon's determination stood her

21 Mary Patterson Clarke to CMA, 24 November 1927, CMAP, Box 26, Folder 309.

22 Mary Patterson Clarke to CMA, 19 August 1930, CMAP, Box 29, Folder 340; Clarke to CMA, 6 March 1932, CMAP, Box 31, Folder 359.

23 Ruth Bourne to CMA, 19 November 1928, CMAP, Box 27, Folder 318; Bourne to CMA,

24 February 1929, CMAP, Box 27, Folder 321.

24 Ruth Bourne to CMA, 29 February 1932, CMAP, Box 31, Folder 358.

25 Bessie E. Hoon to CMA, 26 February 1930, CMAP, Box 28, Folder 334. 
in good stead, as she found a position for two years at Albany College in Oregon and then began the research that would earn her a University of London PhD. Yet even college employment, as others discovered, did not ensure a smooth path. Dora Mae Clark, a physician's daughter from Vermont, who had lamented after gaining her doctorate in 1924 that 'for the first time in my experience history teachers are a drug on the market', nevertheless found a position at Wilson College, but by 1930 found that her research time was severely limited and a leave of absence difficult to negotiate. ${ }^{26}$ Gertrude Ann Jacobsen, meanwhile, was employed at Hunter College in New York as she arranged in 1928 her transfer from the doctoral program at the University of Minnesota to Yale and Andrews, and she too had difficulty obtaining a leave. For Jacobsen, the leave itself was not the problem, but rather her need for half-salary, especially as her father, a minister in Minneapolis, had recently had an accident which 'has rendered my financial status even more precarious'. ${ }^{27}$

While economic issues of this kind were not the concern only of women Cecil Johnson, for example, who would take his $\mathrm{PhD}$ along with Clarke in 1932, wrote to Andrews in early 1928 of having had to pay off a debt load aggravated by his father's serious injury in a car accident - nevertheless, women did not have access to the range of instructorships that were routinely filled through requests sent quietly to Andrews and other senior scholars to recommend 'a man' for any given position. ${ }^{28}$ The informality of such dealings was underlined by Leonard Labaree in September 1929. On a leave from Yale and teaching temporarily at Armstrong College, University of Durham (later the University of Newcastle upon Tyne), Labaree was surprised by the elaborate advertising and interview process that in the United Kingdom went into a junior appointment and commented tersely, 'I must say, I am glad that we do not fill our junior vacancies in that way'. ${ }^{29}$ Women scholars, generally, did not have access to employment at the genuinely research-oriented institutions, and at women's colleges as well as at the smaller coeducational colleges

26 Dora Mae Clark to CMA, 28 August 1924, CMAP, Box 23, Folder 275; Clark to CMA, 27 February 1930, CMAP, Box 28, Folder 334.

27 Gertrude Ann Jacobsen to CMA, 6 April 1928, CMAP, Box 26, Folder 312. For more general discussion of financial stresses on women $\mathrm{PhD}$ students of this era, and their health implications, see Hutchinson, Women and the Ph.D., 38-9.

28 Cecil Johnson to CMA, 1 January 1928, CMAP, Box 26, Folder 311; for one example among many of requests for 'a man', see Beverley W. Bond to CMA, 16 October 1929, CMAP, Box 28, Folder 329.

29 Leonard W. Labaree to CMA, 20 September 1929, CMAP, Box 28, Folder 328. 
that did hire women heavy teaching duties often precluded systematic research activity. ${ }^{30}$ The problem extended, unsurprisingly, into the area of salaries and working conditions, and was compounded not only by the Depression but also by the increasing trend for women's colleges to appoint men to their faculties. A major study of the career trajectories of women holders of doctorates in history noted in 1943 that 'taken as a whole, women taught in smaller and poorer schools ... and, presumably, carried heavier teaching loads for leaner salaries'. ${ }^{31}$

The role of Yale, and of Andrews in particular, in enabling women students and graduates to meet economic and career challenges was complex. By the late 1920s, the Bureau of Appointments was active in placing women as well as men, and in one case in 1928 was experiencing difficulty in finding a woman candidate for a position at Wells College in American history, particularly as both Viola Barnes and Dora Mae Clark preferred to stay in their existing positions at, respectively, Mount Holyoke and Wilson College. 'Do you think of any other possibilities,' the Bureau asked R.H. Gabriel of the Department of History, if not with the Ph.D. at least fairly well along the way toward it?'32 Andrews, meanwhile, was tenacious in efforts to secure funding for both male and female graduate students. 'I know I owe this to you,' observed Isabel MacBeath Calder feelingly on receiving an increased fellowship in 1928, 'It is the kindest thing anyone has done for me for years and far more than I deserve. Thank you. ${ }^{33}$ In 1931, Andrews remonstrated vigorously with the Guggenheim Foundation on behalf of Ruth Bourne, a new $\mathrm{PhD}$ at the time who had not been offered the Guggenheim Fellowship. ${ }^{34}$ And he promoted his graduate students for vacancies at likely institutions, exemplified by Hoon and Calder (unsuccessfully) at Vassar in 1930 and Mildred L. Campbell (successfully) at the same institution in $1932 .{ }^{35}$

30 See, for an example, Patricia Palmieri, 'Here Was Fellowship: A Social Portrait of Academic Women at Wellesley College, 1895-1920', History of Education Quarterly, 23:2 (1983), esp. 210, doi.org/10.2307/368159.

31 William B. Hesseltine and Louis Kaplan, 'Women Doctors of Philosophy in History: A Series of Comparisons', Journal of Higher Education, 14:5 (1943), 256, doi.org/10.2307/1975170; see also Reid, Viola Florence Barnes, 76-7.

32 Sarah Menner, Yale University Bureau of Appointments, to R.H. Gabriel, 10 December 1928, History Department Records (RU 591), Manuscripts and Archives, Yale University Library, 1960-A2002, Box 2, Folder 14 .

33 Isabel MacBeath Calder to CMA, 2 October 1928, CMAP, Box 37, Folder 317.

34 CMA to Henry Allen Moe (copy), 21 November 1931, CMAP, Box 31, Folder 355.

35 Eloise Ellery to CMA, 21, 26 February 1930, CMAP, Box 28, Folder 334; Mildred L. Campbell to CMA, 19 May 1932, CMAP, Box 31, Folder 360. 


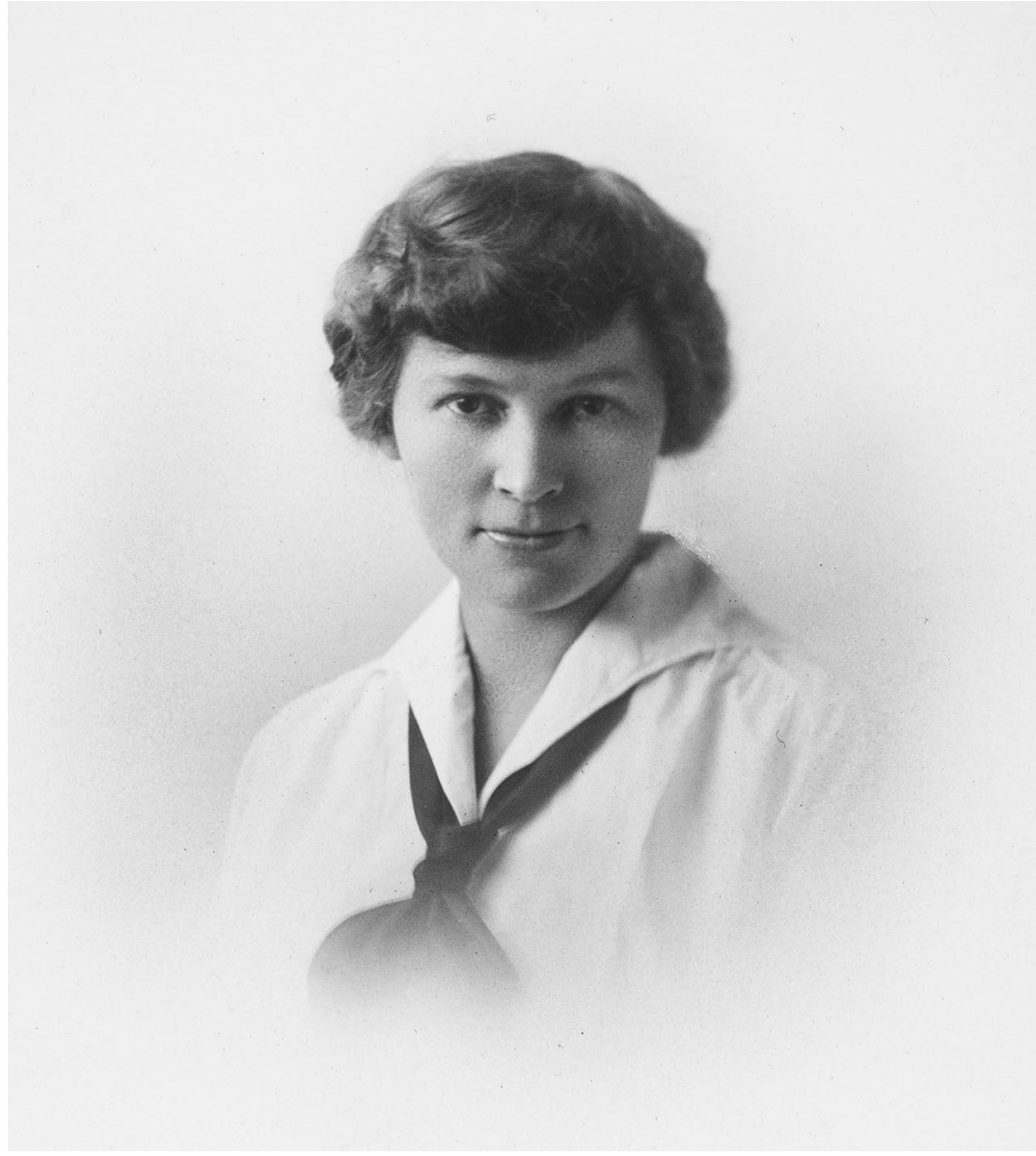

\section{Viola Florence Barnes}

Source: Courtesy of Mount Holyoke College Archives and Special Collections.

Nevertheless, Andrews's advancement of the careers of his women students by this and other means could overbalance at times into being controlling. In 1919, when Viola Barnes took her PhD she had a position being held for her at the University of Nebraska. Andrews, however, pressed her to interview with Neilson for a vacancy at Mount Holyoke, and then urged her to reconsider when she informed him that she would rather return to Nebraska. Barnes ultimately relented and spent the rest of her career at Mount Holyoke, but it was a decision about which she always retained deep misgivings. ${ }^{36}$ Barnes, although she continued to have a profound

36 See Reid, Viola Florence Barnes, 39-40. 
and almost reverential regard for Andrews and Yale, also had other difficult experiences with her mentor. On one occasion, she believed with considerable corroborative evidence - that he had used her research findings without acknowledgement. At another time, he seems to have facilitated access to her recently completed dissertation by James Truslow Adams - self-taught as a historian but winner of the 1922 Pulitzer Prize for his account of The Founding of New England - who, Barnes was convinced, then proceeded to appropriate her ideas for his next book. ${ }^{37}$ Isabel MacBeath Calder's experience was less dramatic but still indicative. She, it must be said, initiated the episode by asking Andrews in 1929 if he could assist in placing essays drawn from her recently completed dissertation on the seventeenth-century New Haven colony in journals that included the New England Quarterly, then edited by Samuel Eliot Morison, who also edited the equally estimable Transactions of the Colonial Society of Massachusetts. Andrews clearly took seriously what he saw as his task, but by April 1931 Calder had become aware that she had entirely lost control of the process. Her exasperation showed in her concern over the fate of one of the essays. 'I do not think,' she wrote to Andrews, 'that you should offer this short paper to anyone else until Mr. Morison has said definitely that he does not want it for the Colonial Society of Massachusetts. It may be that he thinks he has accepted it. ${ }^{38}$ In the meantime, Gertrude Ann Jacobsen had been pleased to have Andrews encourage her - in a session along with Dora Mae Clark - to present a paper drawn from her dissertation research on the seventeenthcentury imperial official William Blathwayt at the annual meeting of the American Historical Association at Duke University in December 1929.

37 These episodes are discussed in Reid, Viola Florence Barnes, 48-52, and in John G. Reid, 'Viola Barnes, the Gender of History, and the North Atlantic Mind', Acadiensis, 33:1 (Autumn 2003), 9-12. Andrews's relationship with James Truslow Adams was odd and complex. Although Adams had no qualifications as a professional historian, and moreover did not let the absence of such restrain him from giving damaging reviews to works published by Andrews's young recent graduate students, nevertheless, Andrews's letters to him were almost deferential in tone, and in 1925 the Yale Graduate School had to quietly turn back an effort on Andrews's part to have Adams appointed to a position at Yale. See, among other items of correspondence in CMAP, Albert S. Cook to CMA, 30 October 1925, CMAP, Box 24, Folder 286.

38 Isabel M. Calder to CMA, 20 August 1929, CMAP, Box 22, Folder 327; Calder to CMA, 4 October 1929, CMAP, Box 28, Folder 328; Calder to CMA, 1 April 1931, CMAP, Box 30, Folder 348; Calder to CMA, 29 April 1931, CMAP, Box 30, Folder 348. The essay eventually appeared in the 1930-1933 Transactions, published in 1935; see www.colonialsociety.org/node/520 (accessed 17 September 2017). 
Even though managing to retain her good humour, Jacobsen found herself a few days before the meeting rewriting the paper to Andrews's specifications:

I quite understand your criticisms and I smile now at my conscious efforts to keep the paper on a general plane, feeling that what you wanted was a presentation of the unity of England's policy at this time and of the common tendencies which displayed themselves in all departments. I shall work at it this weekend using Blathwayt and his activities as the key. ${ }^{39}$

While not all of these experiences were as serious as those of Barnes, there is no indication in Andrews's correspondence of similar pressures being placed on male graduate students. Insofar as Barnes's steering to Mount Holyoke is concerned, Andrews may have had specific motives, beyond his stated rationale that Barnes would be better off to stay close to her archival sources in New England and to the ocean crossing to London, that would have included nurturing his close existing relationship (through Neilson, Ellis and another former student who was a medieval historian there, Bertha Putnam) with the college. However, it was consistent with his efforts to find appointments for others of his women graduate students at Seven Sisters institutions. Even though, for many or most, these were positions they were undoubtedly glad to attain, there was no challenge involved to the orthodoxy that women historians should aspire to careers at women's colleges. ${ }^{40}$ Another area in which Andrews held decided and conventional views was on the incompatibility of graduate study with the intent to marry. Again, Viola Barnes had early experience along these lines. Meeting with Andrews for the first time, before being accepted for PhD work in 1916, Barnes was surprised when he asked if she was engaged to be married, but clearly recalled many years later his explanation: that 'Yale did not encourage women who expected to marry, because the training was such a waste'. ${ }^{41}$ By 1927 , his view was unchanged as he expressed surprise at hearing of the marriage of a promising graduate student, Florence M. Cook (Florence Cook Fast on the Festschrift list), soon after her MA graduation and remarked to his correspondent, Frank J. Klingberg - also

39 Gertrude Ann Jacobsen to CMA, 24 August 1929, CMAP, Box 27, Folder 327; Jacobsen to CMA, 5 October 1929, CMAP, Box 28, Folder 329; Jacobsen to CMA, 12 December 1929, CMAP, Box 28, Folder 331. For evidence of Andrews's orchestration of Clark's paper also, see Dora Mae Clark to CMA, 4 September 1929, CMAP, Box 28, Folder 328.

40 For trenchant comments on the implications of this constraint made by anonymous women $\mathrm{PhD}$ history graduates of the era, see Hutchinson, Women and the Ph.D., 182-5.

41 Viola F. Barnes to [Blanche], 20 December 1958, Mount Holyoke College Archives and Special Collections, Viola Florence Barnes Papers, VIII, 9. 
a Yale $\mathrm{PhD}$ graduate, though before Andrews's time, and a longstanding mentor to Cook from her undergraduate days at UCLA - that 'you were quite right in thinking that she would not have gone back to Yale after her marriage. ${ }^{42}$ Agnes M. Whitson, one of the Commonwealth Fund fellows, wrote to Andrews in 1934 to announce her own impending marriage, and although her tone was playful, the import of her opening anecdote was clear: 'I remember you once saying to me of [one of] your women students "She fell by the wayside, in other words she married."'43

In a revealing contrast, Andrews strongly recommended marriage to his male graduate students. Evangeline Walker Andrews recalled, as cited by A.S. Eisenstadt, that her husband had believed 'that productive scholarship could not proceed without a favourably circumstanced domestic life', and so 'he urged bachelor students to marry and married students to free themselves from encumbering responsibilities at home until they had completed their doctoral work'. ${ }^{44}$ The large majority of his female doctoral graduates, however, remained single. The reasons, naturally, went far beyond Andrews's own influence. Emilie J. Hutchinson noted in 1929, on the basis of a large survey of women PhD graduates across the disciplines, that three-quarters of her respondents were single, even though she did observe that 'women who take the Ph.D. after marriage are more likely to combine gainful employment than those who take it before' and discerned an increasing trend for women $\mathrm{PhDs}$ 'to make this combination of marriage and gainful occupation'. ${ }^{45}$ For most, the reality remained that career and marriage could not be combined, and Bonnie G. Smith has argued that professional women in general and women historians in particular resembled 'a third sex', frequently forming - as did Viola Barnes and no doubt others of the Yale group - close personal relationships with other unmarried women. ${ }^{46}$ Of the women $\mathrm{PhD}$ graduates linked with Andrews, only one appears to have married and then to have had no further academic activity: Helen S. Garrison, who married an earlier Yale $\mathrm{PhD}$ graduate in William H. Dunham, Jr, a member of the Department

42 CMA to Frank J. Klingberg (copy), 22 September 1927, CMAP, Box 26, Folder 27.

43 Agnes M. Whitson to CMA, 20 December 1934, CMAP, Box 34, Folder 390.

44 Eisenstadt, Charles McLean Andrews, 150.

45 Hutchinson, Women and the Ph.D., 17.

46 Bonnie G. Smith, The Gender of History: Men, Women, and Historical Practice (Cambridge, MA:

Harvard University Press), 189-90. 
CLIO'S LIVES

of History at Yale until 1970. Hoon, Frear and Kennedy - as noted above - continued their academic work in various ways, although none had a continuous formal career.

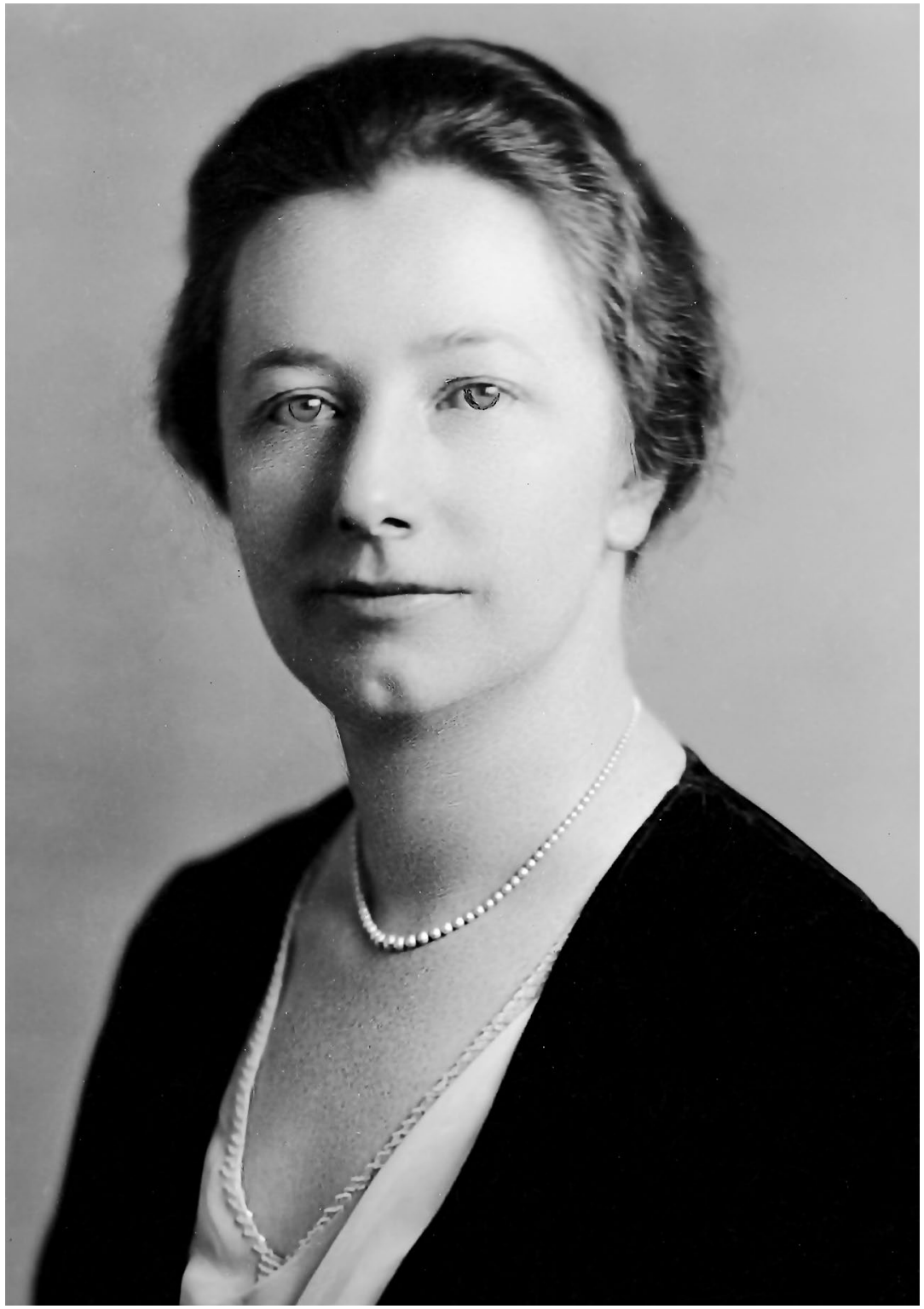

Helen Taft Manning

Source: Courtesy of Bryn Mawr College Library Special Collections. 
The one who, to all appearances, did not allow marriage to impinge on her professional prowess was Helen Taft Manning. Already married to Frederick J. Manning well before they received their respective Yale PhDs in 1924 (Helen) and 1925 (Frederick), she had apparently announced that she was leaving academic employment behind when in 1920 she resigned to get married, after a year - while still well short of her 30th birthday - as acting president of Bryn Mawr. ${ }^{47}$ However, she was approached in 1925 by Marion Edwards Park, the new Bryn Mawr president, about taking up a deanship. Pregnant with her second daughter, she accepted. Although her husband later remarked to Andrews that it was a decision 'I cannot regret', ${ }^{48}$ and his own appointment at Swarthmore soon followed, he may have had misgivings at the time. Writing while Andrews was on a leave in France, Charles Seymour relayed the news in early 1925:

Manning wrote me a long letter some weeks ago, to which I replied giving a personal approval of what he and Mrs. Manning had in mind. I think it is well that he should face now the fact that she would probably not be happy until she had tried her hand at the Bryn Mawr Deanship, and I doubt whether she would be contented to stay on in New Haven as the wife of an Instructor or Assistant Professor for a number of years. ${ }^{49}$

Helen Manning represented, in effect, the exception that proved the rule. While it would be unfair and simplistic to attribute her professional success, as shown in her continuous years at Bryn Mawr until becoming professor emeritus in 1957, primarily to her social origins, as she was a gifted historian and a successful administrator who served another term as acting president in 1929-30, nevertheless she was well placed to subvert gender norms regarding marriage and career. Not only carrying the cachet of being a former president's daughter, she also had the resources to hire a live-in child care nurse. ${ }^{50}$ She also enjoyed an easy and informal relationship with Andrews, who wrote to Evangeline Andrews in June 1930 - who was travelling at the time but, as usual when absent, exchanged lengthy daily letters with her husband:

47 See obituary, 'Helen Manning, Bryn Mawr Dean and Daughter of President Taft', Philadelphia Inquirer, 23 February 1987, p. B06.

48 Frederick J. Manning to CMA, 28 November 1927, CMAP, Box 26, Folder 309.

49 Charles Seymour to CMA, 9 February 1925, CMAP, Box 23, Folder 279.

50 See Frederick J. Manning to CMA, 8 September 1924, CMAP, Box 23, Folder 276. 
yesterday Helen Manning blew in for a talk about her dissertation [as revised for publication], which is approaching completion. I thought she looked tired and worn, for she has had a hard spring, what with her father's death and her duties at Bryn Mawr. But she seemed cheerful and full of energy. ${ }^{51}$

Andrews deliberately did not maintain an office at Yale, so as to avoid interruptions to his work, but if a student - 'man or woman', according to Labaree - visited him at home, he was well known for being open to extended conversation. ${ }^{52}$ It is likely, however, that few if any of the others, students or graduates, 'blew in' as confidently as did Helen Taft Manning.

Quite different was the experience of two of Andrews's MA graduates, Florence Cook Fast and Dorothy S. Towle, who attempted to maintain their research interests in conjunction with marriage and motherhood. Towle was already married at the time of her MA graduation to Carroll $\mathrm{S}$. Towle, another Yale graduate student who would take his $\mathrm{PhD}$ in English in 1933 but had already taken up in 1931 a faculty position at the University of New Hampshire. Dorothy Towle confided to Andrews soon after moving to Durham, NH, that 'you have no idea how much I miss your seminar. It is very difficult to work all alone, but I am doing the best I can until I can put all my [research] problems before you'. ${ }^{53}$ However, caring for a frail mother-in-law was a prelude to child-raising with limited assistance from either husband or hired help and, by 1937, Towle noted that 'my summers are one long nightmare of housekeeping'. ${ }^{44}$ Although she still hoped to apply for a fellowship to advance her research, she was neither in academic employment nor studying for a doctorate and had no illusions about the resulting disadvantages. Even so, Towle had already built sufficiently on her MA work to publish in 1936 a 595-page scholarly edition of eighteenth-century records of the Rhode Island court of vice-admiralty, with an introduction by Andrews. ${ }^{55}$ Later publishing other works of more popular history before her death in 1950 while still

51 CMA to EWA, 17 June 1930, CMAP, Box 29, Folder 338.

52 Leonard W. Labaree, 'Charles McLean Andrews: Historian, 1863-1943', William and Mary Quarterly, 3rd series, 1:1 (January 1944), 11.

53 Dorothy S. Towle to CMA, 30 October 1931, CMAP, Box 31, Folder 354.

54 Dorothy S. Towle to CMA, 24 November 1931, CMAP, Box 31, Folder 355; Towle to CMA, 5 October 1937, CMAP, Box 37, Folder 417.

55 Dorothy S. Towle, ed., Records of the Vice-Admiralty Court of Rhode Island, 1716-1752 (Washington, DC: American Historical Association, 1936). 
in her early 40s, Dorothy Towle had undoubtedly pushed the limits of combining scholarship with reproductive responsibilities, but had found that the limits were at a certain point unyielding.

Florence Cook Fast, daughter of the proprietor of a Los Angeles poultry hatchery and wife of a printer whose California-based enterprises were sometimes fragile during the years of the Depression, took only a few months after her marriage to observe to Andrews:

I have been forced to be utterly domestic, learning how to run a house and more especially how to cook ... I find myself at times quite homesick for New Haven and particularly for the cordial atmosphere of the Graduate Seminar Room. Miss Calder has promised me a letter full of 'gossip' but so far has been too busy to write it ... My marriage, I am afraid, makes it unlikely that I shall return to New Haven for more work. ${ }^{56}$

Almost a year later, she expressed similar feelings about Yale and, working for the time being in the picture department at Gump's art store, she confided the difficulties of finding teaching employment in San Francisco in the face of prejudice against married women. Fast, however, was clearsighted about her life choice and the costs it involved, and resisted any feelings of regret, especially as she had a husband 'who understands my interest in historical work so that it is not difficult to find time to give to it' ${ }^{57}$ The task would become more complicated with the birth of her son in $1932,{ }^{58}$ but over the years she maintained her research ambitions and also - facilitated by Klingberg, and by her husband's willingness to move to Los Angeles - had short-term teaching positions at UCLA. Studying the logwood trade of British Honduras in the colonial era, and able by late 1932 'to take a few hours a day off from infant care', she had thoughts of pursuing a doctorate at Pomona College - conveniently located close to Los Angeles - with Frank W. Pitman, a Yale PhD graduate of 1914 and another signatory to Andrews's Festschrift list. ${ }^{59}$ By 1935, she maintained her ambition but was increasingly forced to recognise the difficulties that would ultimately prove insurmountable. 'I am often envious', Fast wrote, 'of the men whom I knew in New Haven who have married and who have been able to pursue their academic interests without interruption. However, after eight years of marriage I cannot honestly say that I would

56 Florence Cook Fast to CMA, 16 February 1928, CMAP, Box 26, Folder 311.

57 Florence Cook Fast to CMA, 23 January 1929, CMAP, Box 27, Folder 320.

58 Florence Cook Fast to CMA, 8 February 1932, CMAP, Box 31, Folder 358.

59 Florence Cook Fast to CMA, 14 November 1932, CMAP, Box 32, Folder 367. 
have chosen a different course.' She also announced to Andrews - having lacked the courage, she said, to do so hitherto - that she had given her now three-year-old son the middle name 'Andrews', doing so 'as a token of what my two years in New Haven meant to me and as a constant reminder of the things I hope to do in the field to which you introduced me ${ }^{60}$ Tragically, the child died of leukemia at the age of 10 and, according to Klingberg many years later, Fast had carefully kept Andrews's letters, including 'one written to her on the death of her only son [which] is much treasured by her'. ${ }^{61}$

Andrews's continuing mentorship of both Towle and Fast showed that there were more nuances to his views on women scholars and marriage than might have appeared from his direct statements on the matter. To both he offered ongoing encouragement, and his introduction gave a valuable stamp of approval to Dorothy Towle's book, even though it also gave some reviewers the opportunity to review the introduction rather than the book itself. ${ }^{62} \mathrm{He}$ continued to regard Florence Fast as an actively promising researcher, facilitating her publication of an article in North Carolina Historical Review in 1931 and arranging for transcripts of sources relating to the logwood trade to be sent to her from the Public Record Office in London. ${ }^{63}$ Still, in 1938, again in the context of the logwood study, he was 'quite sure that you would be able to write a doctorial [sic] dissertation on the general subject, should you choose to do so' ${ }^{64}$ Yet the constraints imposed by societal convention on married women, like the career limitations that were felt by all aspiring women, went far deeper than mentorship could offset. Networks among women scholars themselves provided some assistance, and Yale scholars were prominent in the most well-organised and effective of all, the Berkshire Conference of Women Historians. Viola Barnes presided over the group from 1933 to 1938, while Mildred Campbell and Helen Taft Manning were also prominent participants. ${ }^{65}$ As well as taking action in the interests of smoothing

60 Florence Cook Fast to CMA, 2 June 1935, CMAP, Box 35, Folder 396.

61 Frank J. Klingberg to EWA, 14 May 1948, CMAP, Box 46, Folder 500.

62 See American Historical Review, 43:2 (January 1938), 403-6, doi.org/10.2307/1839763;

New England Quarterly, 10:2 (June 1937), 408-9, doi.org/10.2307/360050.

63 Florence Cook, 'Procedure in the North Carolina Colonial Assembly, 1731-1770', North Carolina Historical Review, 8:3 (1931), 258-83; A.R. Newsome, North Carolina Historical Commission, to CMA, 11 July 1931, CMAP, Box 30, Folder 351; Florence Cook Fast to CMA, 2 November 1931, CMAP, Box 31, Folder 355.

64 CMA to Florence Cook Fast (copy), 8 November 1938, CMAP, Box 39, Folder 433.

65 See Radcliffe Institute for Advanced Study, Schlesinger Library, Berkshire Conference Papers, passim. 
the paths of younger women scholars into scholarly activities, such as conference presentations and promoting exchange plans that would allow women greater freedom of movement between institutions, the Berkshire group also addressed the issues of gender inequality and contemplated, as recommended by Barnes as president, 'a crusade in the interests of equal opportunity for women in professional competition with men'. ${ }^{66}$

Less formal but undoubtedly sustaining was the network of women scholars that grew up among the Yale-linked historians. Men, of course, networked too, and occasionally gender lines would be crossed. Clarence W. Rife, a PhD graduate of 1922, reported to Andrews in early 1929 on the recent American Historical Association meetings: 'among the Yale students of my day who were present were Malone, Hail, Van Slyck and Miss Helen Gray. I had the pleasure of meeting Miss Barnes who spoke ably at the Luncheon Conference on Colonial and Revolutionary American History ${ }^{6}{ }^{67}$ But there was also a clear separation, with the male network relying principally on meals taken with colleagues at conferences or on research sojourns, supplemented by visitations in summer or at other times of family travel that would involve wives and children but were determined essentially by the random crossing of paths. ${ }^{68}$ Undoubtedly, as well as professionally related exchanges and general gossip, there were gender-related issues to discuss on these occasions, especially for those of the generation directly affected by the First World War. Frederick Manning expressed to Andrews in 1926 the hope that 'the passing of the war generation of graduate students will do something to stop attempts to combine full time teaching, matrimony, and doctors' theses. It can be done, but at a very high cost'. ${ }^{69}$

The women's network, however, was more proactive, including contacts associated with conferences or research travel but also extending to frequent exchanges of news by letter and to visits for the sake of visiting, sometimes across long distances. Key members were the Scottish women who had been at Yale through the Commonwealth Fund, perhaps because they were accustomed to being geographically mobile. Edith MacQueen,

66 Viola Barnes to [Beatrice] Reynolds, 4 May 1937, Mount Holyoke College Archives and Special Collections, Viola Florence Barnes Papers, IV, 47; see also Reid, Viola Florence Barnes, 83-6.

67 Clarence W. Rife to CMA, 4 January 1929, CMAP, Box 27, Folder 320.

68 For examples, see Leonard W. Labaree to CMA, 2 August 1925, CMAP, Box 23, Folder 284; Ralph G. Lounsbury to CMA, 7 August 1925, CMAP, Box 23, Folder 284; Cecil Johnson to CMA, 17 February 1930, CMAP, Box 28, Folder 334.

69 Frederick J. Manning to CMA, 14 May 1926, CMAP, Box 24, Folder 291. 
in January 1929, was on the point of going to New York to visit Gertrude Ann Jacobsen for a few days. ${ }^{70}$ Edith Thomson visited Bessie Hoon in Seattle the following summer. ${ }^{71}$ The following year, Ruth Bourne - in London for research - travelled to Oxford to meet Agnes M. Whitson and her sister. Bourne also reported to Andrews that, at the Public Record Office, 'I have met your student Miss Barnes and find her exceptionally charming ... She has taken a very kind interest in me on your account'. ${ }^{72}$ London was certainly a networking hub, and in 1933 Whitson - who by now had finished her studies at Yale - noted that she was teaching in the Northamptonshire town of Kettering but had been at the Public Record Office during the summer. She had not only lunched daily with Hoon but had also met up with Thomson - who was in London briefly while now living in Malta with her naval officer husband - and another unnamed Yale friend, so that 'we made a Yale quartette several times, at lunch'. ${ }^{73}$ Marriages and, later, warfare made meetings more difficult to arrange, but letters continued to carry both professional and personal news and allow exchanges that were sustaining in both of those areas of life.

In summary, the presence of 50 women's names on the Dedication of Essays in Colonial History to Charles McLean Andrews was significant and revealing, although its nuances require some explication. Andrews was no radical thinker when it came to gender differentiation, and he held conventional views both on marriage and family and on suitable career placements for women historians. There was also a paternalistic element in his dealings with women graduate students that came occasionally to the fore, as experienced by Barnes and others. Nevertheless, collective biography reveals that Yale did at least provide an intellectual environment where it was a matter of routine for the scholarship of women to be valued and nurtured alongside that of men. Whether on his retirement, on his 80th birthday, in letters to Evangeline Andrews following his death, or for no particular reason, women among his former graduate students repeatedly praised Andrews in this vein. Two of the most poignant tributes were delivered in 1940, one from Dora Mae Clark and the other from Edith MacQueen. MacQueen wrote from a small farm that (following several years of production work with the BBC) she had bought in Essex, where she was doing freelance work on war propaganda broadcasts, participating

70 Edith MacQueen to CMA, 23 January 1929, CMAP, Box 27, Folder 320.

71 Bessie E. Hoon to CMA, 5 August 1929, CMAP, Box 27, Folder 327.

72 Ruth Bourne to CMA, 14 August 1930, CMAP, Box 29, Folder 340.

73 Agnes M. Whitson to CMA, 25 September 1933, CMAP, Box 33, Folder 377. 
in local defence and awaiting invasion by the Axis powers. 'At this very grim hour in our country's history,' she avowed, 'I feel I cant [sic] let the moment pass without saying in what may perhaps be a goodbye letter, how very much I appreciate all you have done for me in the past. My years at Yale were some of the happiest in my life and to work with you was a great inspiration. ${ }^{74}$ Clark also wrote with apprehensions for the future, though of a different kind. She was finding it difficult to know how to advise the ambitious among her students at Wilson College. 'Many of them,' she explained, 'want careers. Some of them are very capable; but the graduate schools are becoming exceedingly inhospitable to women. I regret that your attitude toward women students is becoming very rare. ${ }^{75}$ Clark's comment was far-sighted, in the context of the austere climate that would be faced by aspiring women scholars following the Second World War. It also recalled the bleak observations of an earlier generation of women historians who had been quoted in Emilie J. Hutchinson's 1929 analysis. According to one, identified only as a college professor who had gained her $\mathrm{PhD}$ between 1877 and 1915:

the problem for history women is to get a good teaching position in college or university after taking the Ph.D. There are not enough positions to go around because there is a prejudice against women on the part of men in co-educational colleges and in men's colleges. ${ }^{76}$

Andrews and Yale could provide no sovereign remedy for problems that would become more entrenched during the late 1940s and 1950s, and begin only gradually to be addressed thereafter. What did develop, however, was a fragile ecology within which the biographies of women historians could begin from social origins that had some admixture, advance through scholarship that could genuinely thrive and - for a significant number-emerge into life patterns that allowed for the balances between employment and research and between career and family to become negotiable, though always within limits. 
This text is taken from Clio's Lives: Biographies and Autobiographies of Historians, edited by Doug Munro and John G. Reid, published 2017 by ANU Press, The Australian National University, Canberra, Australia.

dx.doi.org/10.22459/CL.10.2017.12 